\title{
PENGARUH MODAL INTELEKTUAL TERDAHAP NILAI PERUSAHAAN DENGAN PROFITABILITAS SEBAGAI VARIABEL MODERASI
}

\author{
Mohammad Herli ${ }^{1}$ \\ Hafidhah $^{2}$ \\ ${ }^{1}$ Dosen Prodi Akuntansi FEB Universitas Wiraraja \\ mohammadherli@wiraraja.ac.id \\ ${ }^{21}$ Dosen Prodi Akuntansi FEB Universitas Wiraraja \\ hafidhah_82@yahoo.com
}

\begin{abstract}
This research is expected to be a reference for readers, especially corporate management to pay attention to intellectual capital in encouraging the increase of company value. The sample of this study consists of companies incorporated in $L Q 45$, the data collected and then analyzed using regression and then the researchers do intrepretasi on the resulting output. The results showed that, intellectual capital affect the value of the company, this is evidenced by the resulting significant value of 0.000 smaller than alpha 0.05. The influence of intellectual capital in lifting company value indicates that company management should pay attention to the management of intellectual capital within the company. Meanwhile, profitability variable which is the moderation variable in this research also proves that the variable is able to moderate the relationship between intellectual capital and firm value.
\end{abstract}

Keywords : intellectual capital, profitability, corporate value

\section{PENDAHULUAN}

Persaingan dunia bisnis semakin kompleks karena tidak hanya bersaing dalam tingkatan lokal, namun telah menjadi persaingan global. Untuk dapat bertahan dalam persaingan tersebut diperlukan inovasi-inovasi bisnis agar satu perusahaan mampu memenangkan persaingan. Salah satu faktor yang menjadi modal yang perlu terus dikembangkan adalah modal manusia yang dalam hal ini adalah tenaga kerja. Perusahaan akan mampu bersaing dan mempertahankan bisnisnya jika memiliki tenaga kerja yang tangguh dan mampu berinovasi bagi pengembangan perusahaan. Kompetensi karyawan dan inovasi dalam akuntansi dianggap sebagai aset tak berwujud yang secara tidak langsung mampu mengangkat performa perusahaan.

Sementara itu dengan semakin berkembangnya ekonomi akhir-akhir ini, keberadaan aset tak berwujud semakin menjadi perhatian dalam meningkatkan performa perusahaan. Hal ini seperti yang diungkapkan oleh Stewart dan Hong dalam (Benny Kuryanto, 2012) bahwa Perkembangan ekonomi baru dapat dikendalikan dengan adanya informasi dan pengetahuan, hal ini dapat memberikan dampak pada peningkatan perhatian modal intelektual (IC). Munculnya "new economy", hal ini disebabkan dengan adanya perkembangan teknologi informasi dan 


\section{FAKULTAS EKONOMI DAN BISNIS UNIVERSITAS WIRARAJA SUMENEP - MADURA}

ilmu pengetahuan, sehingga memicu tumbuhnya minat dalam modal intelektual (Petty dan Guthrie, 2000; Bontis, 2001). Hal yang menjadi pokok perhatian dari para akademisi adalah manfaat dari modal intelektual dalam mengangkat nilai perusahaan.

Oleh karena itu modal intelektual dapat berperan sangat penting dalam aset yang bernilai dalam dunia bisnis modern. Sehingga dapat menimbulkan tantangan bagi para akuntan untuk mengidentifikasi, mengukur, dan mengungkapkannya dalam laporan keuangan. Akuntansi tradisional yang digunakan sebagai dasar pembuatan laporan keuangan dirasa gagal dalam memberikan informasi mengenai IC (Sawarjuwono, 2003). Di lain pihak, para pengguna laporan keuangan membutuhkan informasi kuantifatif dan kualitatif sebagai evaluasi kinerja perusahaan serta informasi mengenai modal intelektual yang dimiliki perusahaan.

Serra Ekowati dkk (2010) bahwa hasil pengujian dengan menggunakan PLS diketahui secara statistik terbukti terdapat pengaruh positif modal intelektual terhadap kinerja perusahaan manufaktur. Namun kesimpulan berbeda disampaikan oleh Benny Kuryanto (2012) dan Divianto (2010) bahwa berdasarkan penelitian yang dilakukan keduanya menyatakan tidak ada pengaruh positif antara IC sebuah perusahaan dengan kinerjanya, semakin tinggi nilai modal intelektual sebuah perusahaan, kinerja masa depan perusahaan tidak semakin tinggi, tidak ada pengaruh positif antara tingkat pertumbuhan modal intelektual sebuah perusahaan dengan kinerja masa depan perusahaan, kontribusi modal intelektual untuk sebuah kinerja masa depan perusahaan akan berbeda sesuai dengan jenis industrinya. Penelitian ini akan menganalisis pengaruh modal intelektual terhadap nilai perusahaan yang dimoderasi oleh variabel kinerja perusahaan yang dalam hal ini diproksikan dengan variabel retur on $\operatorname{asset}(R O A)$.

\section{Kajian Teori dan Kerangka Pikir Penelitian}

\section{Modal Intelektual}

Definisi modal intelektual oleh Organisation of Economic Cooperation and Development (OECD, 1999 dalam Elva Sivana Gining 2012) yang menjelaskan modal intelektual adalah nilai ekonomi dari dua kategori sebagai aset tidak berwujud; (1) organizational (structural) capital; dan (2) human capital. 


\section{FAKULTAS EKONOMI DAN BISNIS UNIVERSITAS WIRARAJA SUMENEP - MADURA}

\section{Profitabilitas Perusahaan}

Rasio profitabilitas atau rasio rentabilitas menunjukkan perusahaan tentang pendapatan/laba yang akan dberikan kepada pada investor. Jika perusahaan mendapatkan laba yang tinggi maka perusahaan memberikan bagian atau deviden kepada investor.

\section{Corporate Value}

Perusahaan dapat dikatakan mempunyai nilai jika kinerja perusahaan menunjukkan nilai baik. Corporate value barkaitan dengan pemberdayaan karyawan dalam suatu perusahaan. Corporate value dapat mencapai tujuan perusahaan secara keseluruhan.

\section{Kerangka Pikir dan Hipotesis}

Penelitian

Kerangka Pikir dalam penelitian ini dapat dirumuskan sebagai berikut:

Gambar 2.1

Kerangka Pikir Penelitian

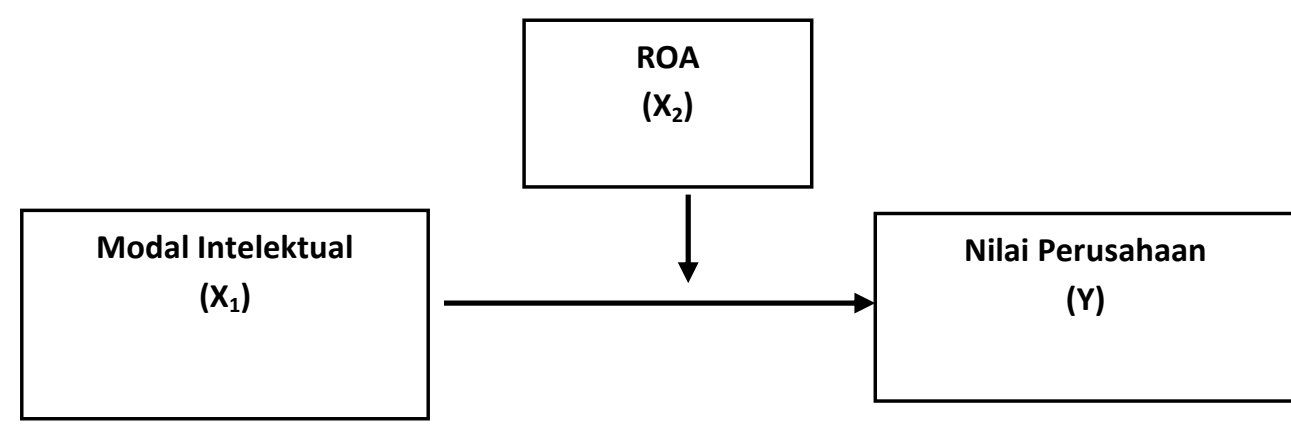

Pengaruh Modal Intelektual terhadap Nilai Perusahaan

\section{Kerangka}

pemikiran

mengenai hubungan antara modal intelektual yang merupakan variabel independen dengan nilai perusahaan sebagai variabel dependen.

Tujuan utama perusahaan adalah meningkatkan nilai perusahaaan. Nilai perusahaan akan terjamin tumbuh secara berkelanjutan (sustainable) apabila perusahaan memperhatikan dimensi ekonomi, sosial dan lingkungan hidup karena keberlanjutan merupakan keseimbangan antara kepentingankepentingan ekonomi, lingkungan dan masyarakat. Karyawan sebagai salah satu kunci dalam mengembangkan nilai perusahaan memegang peranan penting dalam menjamin keberlanjutan perusahaan.

Berdasarkan resource based theory, modal intelektual yang dimiliki perusahaan mampu menciptakan keunggulan kompetitif perusahaan sehingga dapat meningkatkan nilai perusahaan, salah satunya yaitu 


\section{FAKULTAS EKONOMI DAN BISNIS UNIVERSITAS WIRARAJA SUMENEP - MADURA}

meningkatkan laba perusahaan. Dengan adanya penggunaan modal intelektual tersebut diharapkan akan meningkatkan kepercayaan investor terhadap perusahaan serta akan meningkatkan nilai saham perusahaan dan dapat menggunakan sumber daya perusahaan secara efisien dan ekonomis yang dapat membuat peningkatan pada nilai perusahaan.

$\mathrm{H}_{1}$ : Modal intelektual berpengaruh positif terhadap nilai perusahaan

\section{Pengaruh Profitabilitas sebagai} Variabel Moderasi dalam Hubungan antara Modal Intelektual dan Nilai Perusahaan

$$
\text { Profitabilitas perusahaan }
$$

merupakan kemampuan perusahaan dalam menghasilkan laba bersih dari aktivitas yang dilakukan pada periode akuntansi. Profitabilitas dapat menjadi pertimbangan penting bagi investor dalam keputusan investasinya, karena semakin besar dividen (dividend payout) akan semakin menghemat biaya modal, disisi lain para manajer (insider) menjadi meningkat powernya bahkan bisa meningkatkan kepemilikannya akibat penerimaan deviden sebagai hasil keuntungan yang tinggi. Dengan tawaran mendapatkan hasil keuntungan yang tinggi, diharapkan dapat menarik minat investor didalam berinvestasi.

Modal intelektual sebagai bagian yang tidak terpisahkan dalam sebuah perusahaan akan mampu menciptakan efisiensi dalam penggunaan sumber daya perusahaan. Hal ini tentunya akan meningkatkan nilai perusahaan serta laba perusahaan itu sendiri. Selain itu keberadaan modal intelektual dalam suatu perusahaan akan menciptakan keunggulan sehingga nantinya akan menarik investor untuk berinvestasi pada perusahaan tersebut dan pada akhirnya akan meningkatkan nilai perusahaan itu sendiri. Sehingga dapat disimpulkan bahwa, modal intelektual akan meningkatkan nilai perusahaan pada saat profitabilitas perusahaan meningkat.

$\mathrm{H}_{2}$ : Modal intelektual akan meningkatkan nilai perusahaan pada saat profitabilitas perusahaan tinggi.

\section{METODE PENELITIAN}

Jenis Penelitian dan Gambaran dari Populasi Penelitian

Penelitian ini menggunakan pendekatan kuantitatif, karena berusaha membuktikan ada atau tidaknya sebabakibat dari dua variabel.

Teknik Pengambilan Sampel

Penarikan sampel dalam penelitian ini menggunakan teknik purposive sampling atau judgmental sampling. Kriteria yang digunakan untuk 


\section{FAKULTAS EKONOMI DAN BISNIS UNIVERSITAS WIRARAJA SUMENEP - MADURA}

memilih sampel adalah: 1) Perusahaan yang tergolong dalam indeks LQ45 secara terus menerus selama tahun pengamatan (2011-2016); 2) Perusahaan yang mengeluarkan laporan keuangan secara periodik dan memiliki kelengkapan data selama periode pengamatan.

\section{Variabel dan Operasional Variabel}

\section{Variabel Independen}

Variabel bebas dalam penelitian ini terdiri dari variabel modal intelektual $\left(\mathrm{X}_{1}\right)$ dan variabel profitabilitas $\left(\mathrm{X}_{2}\right)$ sebagai variabel moderasi.

\section{Modal intelektual $\left(\mathbf{X}_{1}\right)$}

Modal intelektual yang dalam penelitian ini adalah kinerja Modal intelektual yang diukur berdasarkan value added yang diciptakan oleh employed capital, human capital, dan structural capital.

\section{Profitabilitas $\left(\mathbf{X}_{2}\right)$}

ROA mereflesikan keuntungan bisnis dan efisiensi perusahaan dalam pemanfaatan total aset. Untuk menghitung ROA digunakan rumus sebagai berikut:

$R O A=\frac{\text { Laba Bersih Setela h Pajak }}{\text { Total Aset }}$

\section{Definisi Operasional Variabel: Variabel, Definisi Operasional, Indikator, Skala.}

\begin{tabular}{|c|c|c|c|c|}
\hline No & Variabel & Definisi Operasional & Indikator & Skala \\
\hline \multirow[t]{3}{*}{1} & \multicolumn{4}{|l|}{ Dependen } \\
\hline & \begin{tabular}{|l|} 
a. Modal \\
Intelektual \\
(X1)
\end{tabular} & $\begin{array}{l}\text { Kemampuan intelektual } \\
\text { organisasi yang dapat } \\
\text { juga dianggap sebagai } \\
\text { BPI (Business } \\
\text { Performance Indicator). }\end{array}$ & $\begin{array}{l}\text { VAIC }=\text { VACA+VAHU }+ \\
\text { STVA }\end{array}$ & Skala Rasio \\
\hline & $\begin{array}{l}\text { b. Profitabilitas } \\
\text { (X2) }\end{array}$ & $\begin{array}{l}\text { Rasio profitabilitas } \\
\text { yang mengukur jumlah } \\
\text { profit yang diperoleh } \\
\text { tiap rupiah aset yang } \\
\text { dimiliki perusahaan. }\end{array}$ & $\mathrm{ROA}=\frac{\text { Laba Setelah Pajak }}{\text { Total Aset }}$ & Skala Rasio \\
\hline \multirow[t]{3}{*}{2} & \multicolumn{4}{|l|}{ Independen } \\
\hline & \multicolumn{4}{|c|}{ Kinerja Perusahaan $(\mathrm{Y})$} \\
\hline & Nilai Perusahaan & $\begin{array}{l}\text { Menunjukkan estimasi } \\
\text { pasar keuangan saat } \\
\text { ini tentang nilai hasil } \\
\text { pengembalian dari } \\
\text { setiap dolar investasi } \\
\text { inkremental }\end{array}$ & $\begin{array}{r}Q \\
\frac{(E M V+D)}{(E B V+D)} \\
\vdots\end{array}$ & Skala Rasio \\
\hline
\end{tabular}




\section{FAKULTAS EKONOMI DAN BISNIS UNIVERSITAS WIRARAJA SUMENEP - MADURA}

\section{Teknik Analisa Data}

Analisis data yang digunakan dalam penelitian ini adalah regresi data panel karena data penelitian terdiri dari beberapa tahun pengamatan dan dilakukan pada perusahaan yang berbeda.
Hasil Penelitian dan Pembahasan

\section{Statistik Deskriptif}

Hasil perhitungan statistik deskriptif untuk variabel yang digunakan dalam penelitian ini dapat ditunjukkan pada tabel 4.1 berikut ini :

Tabel 4.1 Statistik Deskriptif

\begin{tabular}{|l|c|c|c|c|}
\hline Keterangan & Minimum & Maximum & Mean & Standar Deviasi \\
\hline IC & 1,09 & 18,53 & 5,61 & 3,54 \\
\hline ROA & 0,09 & 40,38 & 10,43 & 8,59 \\
\hline Q & 0,14 & 18,64 & 2,33 & 2,87 \\
\hline
\end{tabular}

Sumber : Data diolah oleh peneliti

Data statistik yang ditampilkan diatas meliputi data nilai minimum, maksimum, rata-rata, dan standar deviasi dari variabel yang diteliti yaitu : intellectual capital, profitabilitas, dan nilai perusahaan.

\section{a. Intellectual Capital}

Modal intelektual adalah sumber daya pengetahuan dalam bentuk karyawan, pelanggan, proses atau teknologi yang mana perusahaan dapat menggunakannya dalam proses penciptaan nilai bagi perusahaan. Hasil perhitungan statistik dari variabel ini diperoleh nilai rata-rata sebesar 5.61, minimum, 1.09, maksimum 18.53, dan standar deviasi sebesar 3.54.

b. Profitabilitas

Profitabilitas dalam penelitian ini diproksikan melalui Return on Asset (ROA) yang merupakan salah satu rasio profitabilitas yang mengukur efektivitas perusahaan dalam menghasilkan keuntungan dengan memanfaatkan aset yang dimilikinya. ROA mereflesikan keuntungan bisnis dan efisiensi perusahaan dalam pemanfaatan total aset. Berdasarkan hasil perhitungan statistik diperoleh nilai rata-rata sebesar 10.43, nilai minimum 0.09, maksimum 40.38, dan standar deviasi sebesar 8.59.

c. Nilai Perusahaan

Rasio ini menunjukkan estimasi pasar keuangan saat ini tentang nilai hasil pengembalian dari setiap dolar investasi inkremental. Jika rasio Q di atas satu, ini menunjukkan bahwa investasi dalam aktiva menghasilkan laba yang memberikan nilai yang lebih tinggi daripada pengeluaran 


\section{FAKULTAS EKONOMI DAN BISNIS UNIVERSITAS WIRARAJA SUMENEP - MADURA}

investasi. Berdasarkan hasil

perhitungan statistik diperoleh nilai

rata-rata sebesar 2.33, nilai

minimum 0.14, maksimum 18.64,

dan standar deviasi sebesar 2.87 .

\section{Uji Normalitas Data}

Uji normalitas yang digunakan adalah kolmogorof smirnof test. Hasil uji normalitas sebagaimana ditampilkan pada tabel 4.2 berikut ini.

Tabel 4.2 Uji Normalitas Data

\begin{tabular}{|c|c|}
\hline Variabel & Nilai Signifikan \\
\hline IC & 0,111 \\
\hline ROA & 0,230 \\
\hline IC*ROA & 0,287 \\
\hline Q & 0,63 \\
\hline
\end{tabular}

Sumber : Hasil Penelitian

Berdasarkan tabel diatas diperoleh nilai signifikan untuk semua variabel yang diteliti lebih besar dari 0,05 yang berarti data berditribusi normal. a. Uji Normalitas Model

Analisis ini menggunakan analisis grafik seperti tampak pada gambar berikut

ini.

\section{Uji Asumsi Klasik}

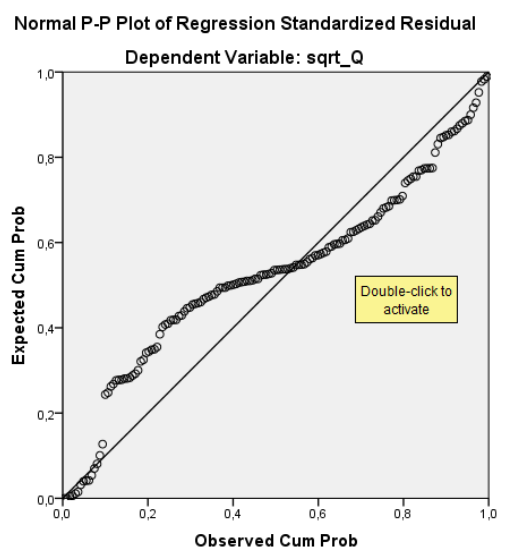

Gambar 4.1 Hasil Uji Normalitas Model

Dari hasil uji normalitas data diatas menunjukkan bahwa data menyebar di sekitar garis diagonal dan mengikuti arah diagonal, maka model regresi memenuhi asumsi normalitas. b. Uji Heteroskedastisitas

Uji heteroskedastisitas dilakukan dengan uji grafik Scatter plot dengan dasar pengambil keputusan. Berikut hasil uji grafik Scatter plot. 


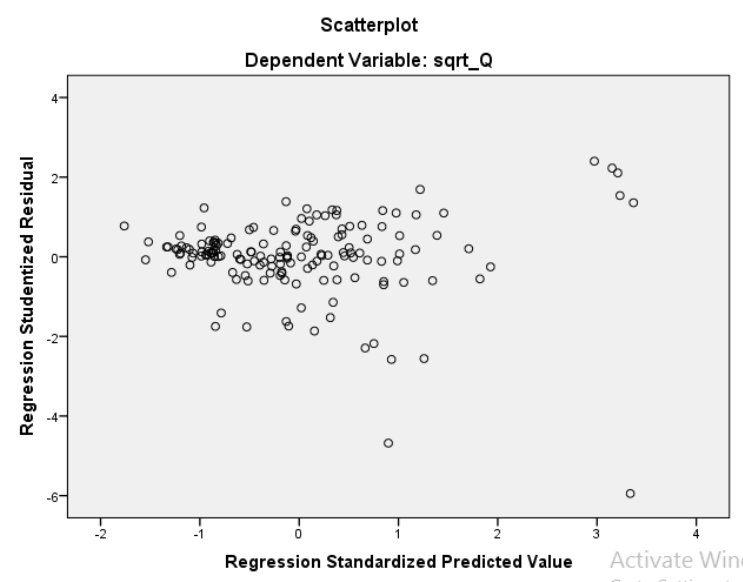

Gambar 4.1 Hasil Uji Heterokedastisitas

Dari hasil uji heterokesdastisitas diatas menunjukkan pada Grafik Scatter Plot tidak terdapat pola yang jelas serta titiktitik menyebar diatas dan di bawah angka nol pada sumbu Y maka model regresi ini tidak terjadi heterokedasitas.

\section{c. Uji Autokorelasi}

Hasil uji autokorelasi menggunakan Durbin Watson bisa dilihat pada table berikut:

Tabel. 4.3 Hasil uji autokorelasi

\begin{tabular}{|l|l|}
\hline$R$ & Durbin Watson \\
\hline 0,661 & 2,180 \\
\hline
\end{tabular}

Tabel 4.3 menunjukkan bahwa uji autokorelasi dengan menggunakan Durbin Watson menunjukkan nilai DW 2.180 lebih besar dari bawas atas (du) 1.77 dan kurang dari 3-1.76 maka dapat dikatakan bahwa tidak terjadi autokorelasi positif dan negatif sehingga dapat disimpulkan tidak terjadi autokorelasi.

\section{Pengujian Hipotesis}

a. Uji t untuk menguji hipotesis 1

Hasil pengujian terhadap hipotesis pertama ditunjukkan pada tabel berikut.

Tabel 4.4 Hasil Uji regresi sederhana

\begin{tabular}{|l|c|c|c|c|c|}
\hline Variabel & $\begin{array}{c}\text { Koefisien } \\
\text { Regresi }\end{array}$ & $\begin{array}{c}\text { Standar } \\
\text { Error }\end{array}$ & $\begin{array}{c}\text { t- } \\
\text { hitung }\end{array}$ & Signifikan & Keterangan \\
\hline Konstanta & 0,868 & 0,057 & 15,35 & 0,000 & \\
\hline ROA & 0,137 & 0,037 & 3,646 & 0,000 & Signifikan \\
\hline $\mathbf{R = 0 , 2 8 2}$ & $R^{2}=0,79$ & Fhitung $=13,294$ & Sig $=0.000$ \\
\hline
\end{tabular}

Sumber : Hasil olah data SPSS 


\section{FAKULTAS EKONOMI DAN BISNIS UNIVERSITAS WIRARAJA SUMENEP - MADURA}

Persamaan regresi linier $\mathrm{Y}=0,868$ $+0,137 \mathrm{X} 1+\mathrm{e}$, yang menunjukkan nilai koefisien regresi yang positif sebesar 0,137, hal ini berarti Intellectual Capital memiliki pengaruh yang positif terhadap nilai perusahaan. Artinya semakin besar nilai Intellectual Capital maka akan semakin meningkatkan nilai perusahaan. Hasil ini diperkuat oleh hasil uji t yang menunjukkan nilai angka signifikansi sebesar 0,000 (lebih kecil dari 0,05) menjelaskan bahwa Intellectual Capital memiliki pengaruh yang signifikan terhadap Nilai Perusahaan. Nilai dari adjusted R-square adalah 0.79 , hal ini berarti $79 \%$ variasi Nilai Perusahaan dapat dijelaskan oleh variasi dari Intellectual Capital, sedangkan sisanya dijelaskan oleh sebab-sebab yang lain di luar model. Dengan demikian hipotesis pertama yang menyatakan "Intellectual Capital berpengaruh terhadap nilai perusahaan" diterima.

\section{b. Uji hipotesis kedua \\ Hasil pengujian terhadap hipotesis} kedua ditunjukkan pada tabel berikut.

Tabel 4.4 Hasil Uji regresi sederhana

\begin{tabular}{|c|c|c|c|c|c|}
\hline Variabel & $\begin{array}{c}\text { Koefisien } \\
\text { Regresi }\end{array}$ & $\begin{array}{c}\text { Standar } \\
\text { Error }\end{array}$ & $\begin{array}{c}\text { t- } \\
\text { hitung }\end{array}$ & Signifikan & Keterangan \\
\hline Konstanta & 1,055 & 0,010 & 15,35 & 102,66 & \\
\hline ABS X1-X2 & 0,024 & 0,024 & 3,646 & 2,109 & Signifikan \\
\hline $\mathbf{R = 0 , 6 5 6}$ & $R^{2}=0,43$ & Fhitung $=38,258$ & \multicolumn{2}{|c|}{ Sig $=0.037$} \\
\hline
\end{tabular}

Sumber : Hasil olah data SPSS

Hasil pengolahan data SPSS menunjukkan bahwa variable moderating ABS X1-X2 ternyata signifikan dengan nilai koefisien regresi (standardized coefficients) sebesar 0,024 dan angka signifikansi sebesar 0,037 dan lebih kecil dari 0,05. Hal ini berarti bahwa variabel ROA merupakan variabel moderating yang memoderasi pengaruh Intellectual Capital terhadap nilai perusahaan. Dengan demikian hipotesis kedua yang berbunyi "Intellectual Capital akan meningkatkan nilai perusahaan pada saat profitabilitas perusahaan tinggi" diterima.

\section{PEMBAHASAN}

\section{Pengaruh Modal Intelektual terhadap nilai perusahaan}

Tujuan utama perusahaan adalah meningkatkan nilai perusahaan. Nilai perusahaan akan meningkat apabila didukung oleh pertumbuhan kinerja perusahaan. Semntara itu kinerja perusahaan erat kaitannya dengan efektifitas manajemen dalam mengelola perusahaan. Dalam arti lain, peran manusia "modal intelektual" memegang peranan penting dalam menciptakan pertumbuhan perusahaan dan kinerja perusahaan. 
Pengujian terhadap hipotesis pertama diperoleh nilai signifikan sebesar 0.000 sehingga hipotesis yang menyatakan modal intelektual berpengaruh terhadap nilai perusahaan terbukti. Ini berarti pasar merespon atas modal intelektual yang dilakukan oleh perusahaan yang tergabung dalam LQ45. Arah hubungan antara modal intelektual dengan nilai perusahaan dilihat pada tabel 4.4 adalah hubungan positif yang berarti modal intelektual dalam perusahaan akan mampu meningkatkan nilai perusahaan. Modal intelektual yang baik dalam sebuah perusahaan akan mampu menciptakan efisiensi sehingga akan mengangkat performa pesusahaan yang pada akhirnya juga akan meningkatkan nilai perusahaan.

Pengaruh Modal Intelektual terhadap nilai perusahaan dengan

profitabilitas sebagai variabel

\section{moderasi}

Pengujian terhadap hipotesis pertama diperoleh nilai signifikan sebesar 0.037 sehingga hipotesis yang menyatakan Profitabilitas (ROA) memoderasi hubungan antara modal intelektual dan nilai perusahaan terbukti. Ini berarti profitabiltas memiliki peranan dalam mingngkatkan hubungan antara modal intelektual dan nilai perusahaan pada perusahaan yang tergabung dalam LQ45. Return on Aset dalam hal ini merupakan salah satu komponen untuk mengukur profitabilitas perusahaan. Efektifitas perusahaan dalam pengelolaan modal intelektual mampu mendorong dalam meningkatkan nilai perusahaan hal ini tentunya akan ditopang oleh profitabilitas perusahaan.

\section{KESIMPULAN DAN SARAN}

\section{Kesimpulan}

Dari hasil penelitian dan pembahasan diatas, dirumuskan simpulan peneltian sebagai berikut :

1. Modal intelektual berpengaruh signifikan terhadap nilai perusahaan. Pengaruh antara modal intelektual dan nilai perusahaan dibuktikan dengan nilai signifikan sebesar 0.000 dan lebih kecil dari alpha 0.05. Arah hubungan modal intelektual dan nilai perusahaan terjadi hubungan yang positif yang mengindikasikan bahwa peningkatan nilai dalam modal intelektual perusahaan juga akan meningkatkan nilai perusahaan itu sendiri.

2. Return on Asset (ROA) yang merupakan proksi dari variabel profitabilitas mampu memoderasi hubungan antara modal intelektual dan nilai perusahaan. Ini dibuktikan dari hasil uji statistik yang memperoleh nilai signifikan 0.037 . artinya profitabilitas mampu memoderasi hubungan antara 
FAKULTAS EKONOMI DAN BISNIS UNIVERSITAS WIRARAJA SUMENEP - MADURA

modal intelektual dan nilai perusahaan.

\section{REFERENSI}

Bontis, N. 1998. "Intellectual Capital: an Exploratory Study that Develops Measures and Models." Management Decision. Vol. 36 No. 2, 63-76.

Kertonegoro, Sentanoe, Prinsip dan teknik Manajemen, Kerja sama penerbit ananda Yogyakarta \& lembaga kerja sama pendidikan tinggi akuntansi swasta seIndonesia.
Linda Dyah Kinasih . 2013. Pengaruh Penerapan Akuntansi Pertanggungjawaban Terhadap Kinerja Manajerial Dengan Motivasi Sebagai Variabel Intervening (Survei Pada Pt Taman Wisata Candi Borobudur, Prambanan,Dan Ratu Boko). jurnal nominal / volume ii nomor ii / tahun 2013

Sawarjuwono, T., \& Kadir, A. P. (2004). Intellectual Capital: Perlakuan, Pengukuran dan Pelaporan (Sebuah Library Research). Jurnal Akuntansi dan Keuangan, 5(1), pp-35. 